\title{
Correction to: Avian Immunome DB: an example of a user-friendly interface for extracting genetic information
}

Ralf C. Mueller ${ }^{1,2^{*}} \mathbb{D}$, Nicolai Mallig ${ }^{1,2,3}$, Jacqueline Smith ${ }^{4}$, Lél Eöry ${ }^{4}$, Richard I. Kuo ${ }^{4}$ and Robert H. S. Kraus , $^{1,2}$

The original article can be found online at https://doi. org/10.1186/s12859-02003764-3.

\section{${ }^{*}$ Correspondence:} rmueller@ab.mpg.de

${ }^{1}$ Department of Migration, Max Planck Institute of Animal Behavior, Am Obstberg, 78315 Radolfzell, Germany

Full list of author information is available at the end of the article

\section{Correction to: BMC Bioinformatics $\quad$ (2020) 21:502 \\ https://doi.org/10.1186/s12859-020-03764-3}

Following publication of the original article [1], the authors identified an error in the author name of Lél Eöry.

The incorrect author name is: Lél Eöery.

The correct author name is: Lél Eöry.

The author group has been updated above and the original article [1] has been corrected.

\section{Author details}

${ }^{1}$ Department of Migration, Max Planck Institute of Animal Behavior, Am Obstberg, 78315 Radolfzell, Germany. ${ }^{2}$ Department of Biology, University of Konstanz, Universitaetsstrasse 10, 78464 Konstanz, Germany. ${ }^{3}$ HTWG Konstanz - University of Applied Sciences, Alfred-Wachtel-Str. 8, 78462 Konstanz, Germany. ${ }^{4}$ The Roslin Institute and Royal (Dick) School of Veterinary Studies, University of Edinburgh, Easter Bush, Midlothian, Roslin EH25 9RG, UK.

Published online: 30 September 2021

Reference

1. Mueller RC, et al. Avian Immunome DB: an example of a user-friendly interface for extracting genetic information. BMC Bioinform. 2020;21:502. https://doi.org/10.1186/s12859-020-03764-3.

Publisher's Note

Springer Nature remains neutral with regard to jurisdictional claims in published maps and institutional affiliations.

(c) The Author(s) 2021. Open Access This article is licensed under a Creative Commons Attribution 4.0 International License, which permits use, sharing, adaptation, distribution and reproduction in any medium or format, as long as you give appropriate credit to the original author(s) and the source, provide a link to the Creative Commons licence, and indicate if changes were made. The images or other third party material in this article are included in the article's Creative Commons licence, unless indicated otherwise in a credit line to the material. If material is not included in the article's Creative Commons licence and your intended use is not permitted by statutory regulation or exceeds the permitted use, you will need to obtain permission directly from the copyright holder. To view a copy of this licence, visit http:// creativecommons.org/licenses/by/4.0/. The Creative Commons Public Domain Dedication waiver (http://creativecommons.org/publicdomain/zero/1.0/) applies to the data made available in this article, unless otherwise stated in a credit line to the data. 